\title{
Effective Leadership and Culture in Iran: An Empirical Study
}

\author{
Ali Dastmalchian* \\ Faculty of Management, University of Lethbridge, Alberta, Canada \\ Mansour Javidan \\ Faculty of Management, University of Calgary, Alberta, Canada
}

Kamran Alam

Faculty of Business, University of Victoria, Canada

\begin{abstract}
On analyse dans cet article les caractéristiques du leadership efficace en Iran, puis on envisage les liens possibles entre ce profil de leadership et les dimensions culturelles du pays. A partir des données fournies par 300 managers provenant de plus de 60 organisations relevant de trois secteurs industriels, on commence par utiliser les dimensions du projet GLOBE pour évaluer la culture iranienne dont les scores sont comparés à ceux d'autres pays. S'appuyant à la fois sur l'emic et l'etic du leadership, les auteurs développent sept dimensions du leadership: encourageant, dictatorial, visionnaire, familial, modeste, loyal et réceptif. Ils soutiennent que certaines de ces dimensions traduisent les aspects universels (ou etic) du leadership (éncourageant, dictatorial), alors que d'autres procèdent de l'emic, c'est-à-dire de la spécificité culturelle du leadership (modeste, familial, loyal). Les résultats sont discutés en terme de positionnement de la culture iranienne entre des entrelacements fondamentaux et des traditions culturelles complexes. On aborde enfin la question des retombées sur les recherches à venir.
\end{abstract}

\section{A GLANCE AT THE LEADERSHIP LITERATURE}

There is no shortage of writing on leadership. Thousands of papers and books have been written on what it means, why it is important, and what

* Address for correspondence: Ali Dastmalchian, Faculty of Management, University of Lethbridge, 4401 University Drive, Lethbridge, Alberta, Canada T1K 3M4, Canada. Email: dastmal@uleth.ca

The authors gratefully acknowledge the assistance of the Industrial Management Institute (IMI) in Iran, and in particular the able assistance of Mohammad Habibi from IMI in data collection. We would also like to acknowledge the assistance and guidance of Mohammad Toloo in the translation. In addition, we would like to express our thanks to Linda Janz, Sarah Howe, Donna Harrison, and Reza (Ray) Yazdani for data analysis and research assistance. 
it takes to be successful. The earliest stream of work is the trait theory of leadership, which concluded that genealogy was at the root of great men reaching positions of power. The overall theme of trait theory is that leaders are special individuals with intelligence, scholarship, persistence, adaptability, and status (Stogdill, 1948, 1974). In the late 1940s and 1950s, researchers started to focus on leaders' behavior rather than traits. The behavioral school converged on four common themes among leaders; support for employees, interaction facilitation, goal emphasis, and work facilitation (e.g. Halpin \& Winer, 1957; Katz \& Kahn, 1952).

The contingency school of leadership is another school of thought and is focused on situational factors such as the task performed by the group, the leader's discretion, and role expectations (e.g. Yukl, 1981). The most recent genre of leadership theories is a confluence of the previous schools of thought. It is alternatively referred to as charismatic leadership (Conger \& Kanungo, 1987; House, 1977), transformational leadership (Bass, 1985, 1997; Tichy \& Devanna, 1986), visionary (Sashkin, 1988), or inspirational (Bennis \& Nanus, 1985). The fundamental premise of this wave of theories is that leaders elevate the needs, values, and aspirations of followers away from selfinterest and towards collective interest. Charismatic leaders have strong selfconfidence, are believed to be competent, are role models, articulate engaging visions and high expectations, and build subordinates' trust (House, 1977; Conger, 1989). Bass (1985) and Yukl (1989) proposed that transformational leaders demonstrate individualised consideration and intellectual stimulation. Burns (1978) suggested that transformational leaders elevate their followers from "everyday selves" to "better selves".

\section{THE ETIC AND EMIC OF LEADERSHIP}

Most of the literature on leadership is based on research in industrialised countries. We have a substantial pool of knowledge from North American and European countries, but our understanding of leadership in other cultures and countries is quite limited. A review of the literature on leadership in other countries prompted Chen and Velsor (1996) to conclude that "there is only a very limited knowledge base regarding leadership behaviors of nontraditional and non-Western leaders". The lack of rigorous research on leaders in other countries poses the question of universality of leadership; to what extent is the Western knowledge on leadership generalisable to other cultures and countries? Over the past 20 years, cross-cultural scholars have been striving to find the answer to this question.

Many researchers have argued for a direct impact of culture on leadership styles. They believe in the "emic" of leadership, arguing that specific cultural traditions, values, ideologies, and social norms are "bound to differentiate as much as or even more than structural factors between societies" (Lammers

(C) International Association for Applied Psychology, 2001. 
\& Hickson, 1979, p. 10). Hofstede and his colleagues provided further evidence that leadership style varies according to cultural clusters, as measured by how an individual scored on his four original cultural dimensions (Hofstede, 1980) and his subsequent fifth dimension (Hofstede \& Bond, 1988). Erez and Earley (1993) have also argued for the impact of culture on leadership style and employee behavior. They suggested that cultural norms help shape the manager's and the employee's psychological experience of self-identity and help generate the criteria that are used to assess a manager's performance.

On the other hand, there are those researchers who believe in the "etic" of leadership, arguing that at least some aspects of leadership transcend national cultures and are universally accepted. They maintain that increasingly common technological imperatives (Woodward, 1958), common industrial logic (Adler, Doktor, \& Redding, 1986), generally accepted accounting principles, and global institutions all serve to harmonise management practices and structures (Child \& Tayeb, 1983; Levitt, 1983; Yavas, 1995). Bernard Lewis (1995) provided an interesting account of cultural convergence in his description of a man sitting at a table in a coffee shop in a Middle Eastern city: "Drinking a cup of coffee or tea, perhaps smoking a cigarette, reading a newspaper, playing a board game, and listening with half an ear to whatever is coming out of the radio or the television installed in the corner." On a closer look, this coffeehouse man, "probably wears Western style clothes - sneakers, jeans, a T-shirt. The chair at which he sits, the coffee he drinks, the tobacco he smokes, the newspaper he reads, all are Western imports. The radio and television are Western inventions. If our relaxing friend is a member of his nation's army, he probably operates Western or soviet weapons and trains according to Western standards; if he belongs to the government, both his bureaucratic surroundings and the constitutional trappings of his regime may owe their origins to Western influence" (The Economist, 1996). Lewis's conclusion is that "In modern times, the dominating factor in the consciousness of most Middle Easterners has been the impact of Europe, later of the west more generally, and the transformation - some would say dislocation - which it has brought" (1995, in The Economist, 1996, p. 26).

Perhaps the most comprehensive and consistent set of research evidence for this school relates to the work on transformational leadership (Bass, 1985, 1997). The strength of the empirical support for transformational leadership led Bass to conclude that while cultural influences do exist, "nonetheless, certain generalizations appear warranted. The ideals and implicit theories of leadership tend to be transformational rather than transactional" (1997, p. 137). While these two observations indicate some degree of acceptance of the concept, universality has not generally enjoyed strong support in the management literature and the debate goes on.

(C) International Association for Applied Psychology, 2001. 


\section{THE PRESENT STUDY}

\section{The Purpose}

The purpose of this study is to help improve our understanding of the etic and emic of leadership by examining the implicit theory of leadership in a non-Western society. Our intent is not to conduct a cross-cultural study, rather to provide an in-depth understanding of leadership effectiveness in a society with a widely different culture from Western societies. We will show the profile of effective organisational leaders as described by a large sample of Iranian middle managers in different industries. We will then compare our findings with the Western leadership literature to identify similarities and differences.

\section{Present-day Iran}

Iran has long served as a nexus for trade and culture between East and West. The largest and most populous nation of the Middle East, it harbors in its $1,648,000$ square kilometers a wide assortment of climates, landscapes, and ethnicities. The country shares over 1,500 kilometers of its northern border with the formerly Soviet Central Asian Republics and Caucasus region, some 650 kilometers of which comprise the southern coast of the Caspian Sea. The Azerbaijan highlands divide Iran from Turkey, its neighbor to the north-east while further to the south the Zagros Mountains tower over Khuzestan, Iran's rich oil producing region. To the east, the vast Dasht-eKavir and Dasht Lut deserts sweep into Afghanistan and Pakistan.

Iran's role as a major trade route can be traced as far back as the fourth century BC when during what was known as the Persian Empire, the forerunner of modern Iran, the Silk Road was established linking Iran to China, Europe, Asia, and the Middle East. Always known for its rich culture and abundant resources, Iran's geographic position has placed it as a primary link between civilisations.

Iran possesses the largest market in the Middle East, with a population exceeding the combined total of all countries in the Persian Gulf region, sharing borders measuring some 2,000 kilometers with the newly independent Central Asian Republics representing a further market of some 100 million people, Afghanistan to the east and the Persian Gulf states to the south, presents a potential market of over 200 million people.

According to the last census in 1989 the population of Iran stood at 58 million people. The figure for 1996 stood at 60 million (United Nations, 1997). The population is mostly urban (35 million, UN Statistical Yearbook, 1997), very young $(70 \%$ of the population is under the age of 30 , UN Statistical Yearbook, 1997), and evenly distributed in terms of gender

(C) International Association for Applied Psychology, 2001. 
(UN Statistical Yearbook, 1997). The country's GDP in 1995-96 was almost 61 billion US dollars, and the per capita GDP stood at \$1,000 US dollars. During 1994-95, it exported almost 20 billion US dollars while its imports amounted to almost 12 billion US dollars. Oil and gas accounted for the lion's share of its exports, at 75 per cent (1999 Britannica Book of the Year). Iran's three biggest partners are Italy, Germany, and Japan (The Europa World Year Book, 1997, Vol. 1).

Tehran, Mashad, Tabriz, Isfahan, and Shiraz are the most populous cities in Iran. Iranian society comprises various ethnicities each with their own specific traits. The Persians, Turks, Turkomans, Lors, Baluchis, Kurds, and Arabs account for the major ethnic groups. These various ethnicities share much in history; however, they maintain cultural and language differences. It is important to recognise that Iran is not ethnically homogenous, although to the outside world it may seem to be the case.

According to Article 15 of the Iranian Constitution, the common language and alphabet of the Iranian people is Farsi (Persian, as it was previously known). All official documents, texts, and textbooks are written in this language, while the use of local dialects and other ethnic symbols in the press, popular media, and educational system alongside the Farsi language is widespread. Moreover, according to Article 16 of the Constitution, teaching and learning of the Arabic language is mandatory as the language of the Holy Quran and as part of the Islamic education curriculum in all grades. Aside from the Farsi language, Lori, Baluchi, and other dialects common to various tribes and ethnicities are widely spoken.

According to the 1986 census, 99.4 per cent of the population of Iran adheres to Islam and according to Article 12 of the Iranian Constitution, the "Ja'afari Ithnee Ashari" (simply identified as Shiite Muslim by the West) branch of Islam is the official religion of the country. In addition to this and other Muslim sects, as per Article 13 of the Constitution, Zoroastrians, Jews, and Christians are officially recognised as religious minorities and are free to practise their faiths and adhere to their customs.

\section{The Literature on Iranian Leadership}

The extant literature on Iranian leadership is rather sparse. A computer search on the topic produced a very small number of publications. In a comparative study of Iranian and Canadian managers, using a sample of 106 Canadian and 158 Iranian managers, Javidan and Dastmalchian (1993) found that there are some significant differences in effectiveness criteria and roles for the managers in the two cultures. In a survey of 143 Iranian executives, Javidan (1994; Javidan \& Dastmalchian, 1995) and Dastmalchian and Javidan (1998) found the concepts of visionary and high-commitment leadership as developed by such authors as Kotter (1988), Conger (1989),

(C) International Association for Applied Psychology, 2001. 
and Tichy and Devanna (1986) was confirmed within the Iranian sample. They showed that the Iranian view of a visionary leader is one who has a mental map, shares a new paradigm, has a global outlook, is enthusiastic about and dedicated to his/her vision, and is a credible communicator. These findings also showed that visionary leaders are highly valued and respected by their subordinates. These findings were also reinforced in a study comparing Iranian and Taiwanese managers (Javidan \& Dastmalchian, 1995). In another study, Javidan (1996), in a survey of over 100 Iranian executives, found strong empirical support for Conger and Kanungo's concept of empowerment (1987). The results also showed that those executives who performed these practices left a strong emotional impact on their subordinates and built a loyal workforce.

\section{RESEARCH METHODOLOGY: THE GLOBE PROJECT}

The data for this paper were collected as part of the GLOBE research project. A detailed account of this project is provided in House et al.'s recent article (1999). GLOBE (Global Leadership and Organisational Behavior Effectiveness) is a multi-phase, multi-method project initiated by Robert House in 1993. Over 170 social scientists and management scholars from 61 countries in all major regions throughout the world have been engaged in the study of the relationship between culture and leadership. GLOBE was designed to investigate the existence of universally acceptable and universally unacceptable leadership attributes, and to identify those attributes that are culture specific. The theoretical base of this research program is grounded in the notion of implicit theory of leadership which argues that individuals have implicit theories about the attributes and behaviors that distinguish leaders from others, effective leaders from ineffective leaders, and moral from evil leaders (House, Ruiz-Quintanilla, Dorfman, Javidan, Dickson, \& Gupta, 1999). The GLOBE team reached consensus on the definition of the two central concepts: societal culture and leadership. They defined leadership as "the ability of an individual to influence, motivate, and enable others to contribute toward the effectiveness and success of the organisations of which they are members" (House et al., 1999, p. 10). Societal culture was defined as "the commonality among members of collectives with respect to the psychological attributes ... and the commonality of observed and reported practices of entities such as families, schools, work organizations, economic and legal systems, and political institutions" (House et al., 1999). Expanding on Hofstede's (1980) work, GLOBE focused on eight cultural dimensions: uncertainty avoidance, power distance, societal collectivism, in-group collectivism, gender egalitarianism, assertiveness, future orientation, humane orientation, and performance orientation.

(C) International Association for Applied Psychology, 2001. 
The leadership instrument was a comprehensive list of 166 leader attributes and behaviors. The details of scale development and the rigorous psychometric analyses are provided elsewhere (House et al., 1999; Den Hartog, House, Hanges, Ruiz-Quintanilla, \& Dorfman, 1999). The leadership questionnaire asked each respondent to use a scale of 1 to 7 to indicate the extent to which a particular attribute helps or hinders effective leadership. The following are a few examples:

$\begin{array}{llllllll}\text { Autocratic } & 1 & 2 & 3 & 4 & 5 & 6 & 7 \\ \text { Charismatic } & 1 & 2 & 3 & 4 & 5 & 6 & 7 \\ \text { Decisive } & 1 & 2 & 3 & 4 & 5 & 6 & 7\end{array}$

\section{Scale}

$1=$ This behavior or characteristic greatly inhibits a person from being an outstanding leader.

$2=$ This behavior or characteristic somewhat inhibits a person from being an outstanding leader.

$3=$ This behavior or characteristic slightly inhibits a person from being an outstanding leader.

$4=$ This behavior or characteristic has no impact on whether a person is an outstanding leader.

$5=$ This behavior or characteristic contributes slightly to a person being an outstanding leader.

$6=$ This behavior or characteristic contributes somewhat to a person being an outstanding leader.

$7=$ This behavior or characteristic contributes greatly to a person being an outstanding leader.

\section{Sample and Data Collection}

As part of GLOBE, 300 Iranian middle managers in three industries participated in this study. They were from banking (37\%), telecommunications $(31 \%)$, and food processing $(32 \%)$. The reason for the selection of these particular industries was the consensus among GLOBE researchers that they exist in all the participating countries. All the questionnaires were translated into the Iranian language, Farsi, and back-translated to English. The respondents were from over 60 organisations, occupying middle to high-level managerial positions (55\% department heads or equivalent, with $30 \%$ in positions higher than a department head and the remaining $15 \%$ mostly staff professionals). The average age of the respondents was 42.1, with an average of 19.3 years of work experience, and an average of 12.6 years in the same organisation. Over 85 per cent of those who responded to the education level question had a university degree. (The number of

(C) International Association for Applied Psychology, 2001. 
responses to the demographic questions ranged from 189 to 229.) Responses per organisation ranged from 1 to 30 . The average size of the organisations represented was 6,944 employees. The data collection process was completed during 1994 to 1996.

\section{RESULTS}

In this section, we will present the findings of our research in two parts: the first part will report the findings on the Iranian culture, and the second part will report the findings on the profile of effective Iranian leaders.

\section{Findings on Iran's Societal Culture based on GLOBE's Dimensions}

As previously indicated, GLOBE measured societal culture using nine cultural attributes. The results of the societal culture for our sample are shown in Table 1. As shown in the table, for all the cultural dimensions except for power distance and in-group collectivism, the "should be" scores are higher than the "as is" scores. That is, the respondents feel that, on balance, the societal culture in Iran should change in that more uncertainty

TABLE 1

Societal Culture Dimensions

\begin{tabular}{|c|c|c|c|c|c|c|c|c|}
\hline & \multicolumn{4}{|c|}{ Iranian Data } & \multicolumn{4}{|c|}{ Overall GLOBE Data ${ }^{\text {a }}$} \\
\hline & \multicolumn{2}{|c|}{ As Is } & \multicolumn{2}{|c|}{ Should Be } & \multicolumn{2}{|c|}{ As Is } & \multicolumn{2}{|c|}{ Should Be } \\
\hline & Mean & $S D$ & Mean & $S D$ & $\begin{array}{l}\text { Highest } \\
\text { Score }\end{array}$ & $\begin{array}{l}\text { Lowest } \\
\text { Score }\end{array}$ & $\begin{array}{l}\text { Highest } \\
\text { Score }\end{array}$ & $\begin{array}{c}\text { Lowest } \\
\text { Score }\end{array}$ \\
\hline 1. Uncertainty Avoidance & 3.67 & 0.98 & 5.36 & 0.76 & 5.37 & 2.88 & 5.61 & 3.16 \\
\hline 2. Gender Egalitarianism ${ }^{\mathrm{b}}$ & $2.99^{\mathrm{a}}$ & 1.02 & $3.75^{\mathrm{b}}$ & 0.56 & 4.08 & 2.50 & 5.17 & 3.18 \\
\hline $\begin{array}{l}\text { 3. Collectivism I: Societal } \\
\text { Collectivism }\end{array}$ & 3.88 & 0.93 & 5.54 & 0.72 & 5.22 & 3.25 & 5.62 & 3.83 \\
\hline $\begin{array}{l}\text { 4. Collectivism II: } \\
\text { In-Group Collectivism }\end{array}$ & 6.03 & 0.57 & 5.86 & 0.76 & 6.36 & 3.18 & 6.52 & 4.06 \\
\hline 5. Humane Orientation & 4.23 & 0.98 & 5.61 & 0.72 & 5.23 & 3.18 & 6.09 & 3.39 \\
\hline 6. Power Distance ${ }^{\mathrm{b}}$ & $5.43^{\mathrm{b}}$ & 0.93 & $2.80^{\mathrm{b}}$ & 0.80 & 5.80 & 3.25 & 4.35 & 2.04 \\
\hline $\begin{array}{l}\text { 7. Performance } \\
\text { Orientation }\end{array}$ & 4.58 & 0.86 & 6.08 & 0.60 & 4.94 & 3.20 & 6.58 & 2.35 \\
\hline 8. Future Orientation & 3.70 & 0.92 & 5.84 & 0.63 & 5.07 & 2.88 & 6.20 & 2.95 \\
\hline 9. Assertiveness & 4.04 & 0.73 & 4.99 & 0.65 & 4.80 & 3.36 & 5.56 & 2.66 \\
\hline
\end{tabular}

a Based on data reported on GLOBE's Home Page

${ }^{b}$ These scales have fewer items than the GLOBE scales

(C) International Association for Applied Psychology, 2001. 
avoidance, more gender egalitarianism, higher levels of societal collectivism, more humane orientation, more performance orientation, more future orientation and assertiveness should be the norm in the society. Power distance on the other hand is perceived to be high and the perception of the individuals surveyed is that the emphasis on this aspect of culture should be reduced. In-group, or family, collectivism is another cultural dimension that according to the data should be less emphasised.

Table 1 also shows the range of scores for "as is" and "should be" scales for the entire GLOBE sample of 61 countries. Comparing the "as is" scores of the Iran data with the GLOBE, it is evident that the Iranian sample score fairly high for power distance and in-group collectivism. In fact in terms of in-group collectivism, Iran's mean score for the "as is" scale was 6.03 as compared with the overall GLOBE range of 6.52-4.06. Iran in fact has the third highest score on this dimension (after the Philippines and Georgia). A prominent feature of the Iranian societal culture is the extent to which they demonstrate loyalty, express pride and cohesiveness towards family, organisations and other in-group collectivities. This is a sharp contrast to the picture that emerges when we considered societal collectivism. Iran scored comparatively quite low on this dimension with a mean score for "as is" societal collectivism of 3.88. The overall GLOBE range for societal collectivism was 5.22-3.25 (Iran in fact was the 13th lowest country in terms of ranking on this dimension). Therefore, the results show that Iran has one of the lowest scores on societal collectivism while it shows one of the highest scores on in-group collectivism.

On power distance, given that the scale for Iran data has one fewer item than the GLOBE scale (one question had to be deleted due to its sensitivity), one cannot make the same comparison as in the case of collectivism dimensions. However, it is apparent from Table 1 that Iran scores comparatively quite high on this dimension (Iran's score of 5.43 compared with the maximum of 5.80; the ranking was 14 out of 61). That is, according to the respondents the present societal norm reflects an unequal sharing of power in the society. The "should be" score on this dimension of culture is equally quite revealing, in that the desire of the society to alter this aspect of the culture is by far the greatest among all the dimensions of culture under study (the absolute difference between the "as is" and the "should be" scores is highest for power distance, and lowest for in-group collectivity).

The results also show that Iran scored in the lower range in the GLOBE sample for assertiveness "as is" (Iran's mean score was 4.04, which was the 24th country from lowest in the GLOBE list). That is, Iranians are less confrontational and aggressive in social relationships (the other countries which scored close to the Iranian sample were: Canada 4.05; the Philippines 4.00; Slovenia 3.92; Ireland 3.92; and Taiwan 3.91). The lowest assertive nation was Sweden (3.38) and the highest was Albania (4.80).

(C) International Association for Applied Psychology, 2001. 
Among the other more interesting observations regarding societal culture was the finding that gender egalitarianism is not highly emphasised (in a comparative sense, allowing for the fact that this dimension has fewer items than the GLOBE measure, Iran's score on gender egalitarianism is 8th lowest score among the 61 countries). That is, the norm in the society is to maximise, or at least not to minimise, gender role differences and gender discrimination. Another noteworthy observation is that there does not appear to be a strong desire in the society to change this (the absolute difference between "as is" and "should be" scores is 0.76 - the second lowest among the nine dimensions). Humane orientation, on the other hand, is a strong societal cultural norm in Iran in that being altruistic, friendly, generous, caring, and kind to others is highly emphasised and rewarded (Iran's score is 4.23 which is in the top $30 \%$ of the ranking of the 61 countries). The results reported in Table 1 also show that the societal norms in Iran support performance orientation, improvement, and excellence (Iran's score on performance orientation "as is" was 4.58 , while the maximum score for all the countries was 4.94-Iran ranked 8th). Future orientation as a cultural value receives relatively low emphasis in Iran (score of 3.70 for "as is"-ranks 20th from the lowest in the GLOBE sample) indicating that planning, investing, and future oriented behaviors are not highly emphasised. However, comparing the difference between "as is" and "should be" scores from Table 1 indicated that this dimension received the second highest absolute value. That is, the desire to make future orientation a societal norm is very high according to the respondents. Similarly, uncertainty avoidance as a cultural value is not highly emphasised (Iran scored 3.67, 8th lowest score amongst the 61 GLOBE countries). However, there appears to be a desire to change that (as reflected in the "should be" score, and the absolute difference between "as is" and "should be" scores).

In summary, the data reported in this study show that the societal culture in Iran is characterised by a strong cultural value on in-group collectivism, low uncertainty avoidance, high performance orientation, high power distance, and low societal collectivism. A moderate emphasis on humane orientation and moderately low assertiveness and future orientation are also among the cultural attributes of Iranian society.

\section{Findings on Leadership}

In order to measure the attributes of effective leadership among the Iranian managers studied, the initial leadership items in the GLOBE list were measured using a pilot study. As a result a final list of 166 leadership attributes were included in the final questionnaire (this process followed Phase I and Phase II of Globe as described by House et al., 1999). In an attempt to examine the patterns of leadership identified by the Iranian

(C) International Association for Applied Psychology, 2001. 
sample, the items were factor analyzed using varimax rotation. The results are shown in Table 2.

TABLE 2

Summary of Leadership Results from Factor Analysis

\begin{tabular}{|c|c|c|c|c|c|c|c|}
\hline Examples of Items & $\begin{array}{l}\text { Factor } 1 \\
\text { Supportive }\end{array}$ & $\begin{array}{c}\text { Factor } 2 \\
\text { Dictatorial }\end{array}$ & $\begin{array}{c}\text { Factor } 3 \\
\text { Planner }\end{array}$ & $\begin{array}{l}\text { Factor } 4 \\
\text { Familial }\end{array}$ & $\begin{array}{c}\text { Factor } 5 \\
\text { Humble }\end{array}$ & $\begin{array}{c}\text { Factor } 6 \\
\text { Faithful }\end{array}$ & $\begin{array}{l}\text { Factor } 7 \\
\text { Receptive }\end{array}$ \\
\hline 1. Encouraging & 0.73 & & & & & & \\
\hline 2. Robust & 0.71 & & & & & & \\
\hline 3. Sincere & 0.71 & & & & & & \\
\hline 4. Understanding & 0.70 & & & & & & \\
\hline $\begin{array}{l}\text { 5. Socially } \\
\text { Supportive }\end{array}$ & 0.70 & & & & & & \\
\hline 6. Egotistical & & 0.70 & & & & & \\
\hline 7. Non-cooperative & & 0.68 & & & & & \\
\hline 8. Non-delegator & & 0.68 & & & & & \\
\hline 9. Autocratic & & 0.64 & & & & & \\
\hline 10. Ruthless & & 0.64 & & & & & \\
\hline 11. Plans Ahead & & & 0.74 & & & & \\
\hline 12. Foresight & & & 0.66 & & & & \\
\hline 13. Orderly & & & 0.62 & & & & \\
\hline 14. Informed & & & 0.60 & & & & \\
\hline 15. Visionary & & & 0.58 & & & & \\
\hline 16. Home-oriented & & & & 0.63 & & & \\
\hline 17. Loyal I & & & & 0.50 & & & \\
\hline 18. Familial & & & & 0.49 & & & \\
\hline 19. Habitual & & & & 0.47 & & & \\
\hline 20. Domestic & & & & 0.44 & & & \\
\hline 21. Humble & & & & & 0.61 & & \\
\hline 22. Subtle & & & & & 0.53 & & \\
\hline 23. Custodial & & & & & 0.52 & & \\
\hline 24. Self-effacing & & & & & 0.48 & & \\
\hline 25. Hard-working & & & & & 0.41 & & \\
\hline 26. Faithful & & & & & & 0.76 & \\
\hline 27. Religious & & & & & & 0.74 & \\
\hline 28. Devout & & & & & & 0.68 & \\
\hline 29. Orthodox & & & & & & 0.67 & \\
\hline 30. Patriotic & & & & & & 0.55 & \\
\hline 31. Clear & & & & & & & 0.55 \\
\hline 32. Anticipatory & & & & & & & 0.49 \\
\hline 33. Benevolent & & & & & & & 0.48 \\
\hline $\begin{array}{l}\text { 34. Administratively- } \\
\text { skilled }\end{array}$ & & & & & & & 0.44 \\
\hline 35. Aesthetic & & & & & & & 0.39 \\
\hline No. of Items & 46 & 38 & 12 & 11 & 10 & 8 & 10 \\
\hline Eigenvalue & 26.3 & 13.0 & 6.3 & 5.8 & 5.0 & 3.6 & 3.5 \\
\hline $\begin{array}{l}\% \text { of variance } \\
\text { explained }\end{array}$ & 16.6 & 24.8 & 28.8 & 32.5 & 35.7 & 38.0 & 40.2 \\
\hline
\end{tabular}

(C) International Association for Applied Psychology, 2001. 
As shown in Table 2, the initial outcome was a seven-factor solution involving 112 of the items. These were: supportive, dictatorial, visionary, familial, humble, faithful, and receptive. Table 2 shows sample items from each factor, number of items for each factor, eigenvalues and percentage of variance explained for each factor. Table 3 shows additional information on each of these seven Iranian leadership scales. It shows number of items for each scale, means and standard deviations, range and the coefficient alpha (internal consistency reliability coefficient). More detailed information including details of all the items for each factor is provided in the Appendix. As shown in Table 3 all the leadership scales have high internal consistency reliability coefficients (alphas) and are quite acceptable.

The first two factors (supportive and dictatorial) resemble the GLOBE leadership factors of "value-based" or charismatic and "narcissistic" leadership attributes (House et al., 1999; Den Hartog et al., 1999, 2000), which have also been reported in GLOBE's specific country or region findings (e.g. see Ashkanasy, Kennedy, \& Trevor-Roberts, 2000, for findings relating to Australia and New Zealand). They refer to the "etic" aspect of leadership and may provide further evidence on the universality of certain configurations of leadership behaviour (see the Introduction to the GLOBE Project in this issue by House, Javidan, \& Dorfman).

The third factor, which we called planner, refers to the future and planning orientation of the leader's behavior. Given the earlier comments regarding the future orientation dimension of Iranian culture and their desire to place this at the forefront of their list of "should be" cultural traits, this leadership dimension portrays a particular type of attribute that is tied into the post-revolution organisational and social issues in Iran (e.g. Goreishi \& Zahedi, 1997; Fairbanks, 1997; Rouleau, 1995). That is, if the desire to instill and cultivate more future orientation is indeed paramount,

TABLE 3

Means, Standard Deviations, Range, Reliability Coefficients of Leadership Factors

\begin{tabular}{lcccccc}
\hline Factor & $\mathrm{N}$ & $\begin{array}{c}\text { No. of } \\
\text { Items }\end{array}$ & Mean & SD & Range & $\begin{array}{c}\text { Reliability } \\
\text { Coefficient } \\
\text { ( } \boldsymbol{\alpha})\end{array}$ \\
\hline 1. Supportive & 286 & 46 & 5.92 & 0.33 & $4.8-6.5$ & 0.96 \\
2. Dictatorial & 273 & 38 & 2.42 & 0.92 & $1.3-6.3$ & 0.94 \\
3. Planner & 294 & 12 & 6.18 & 0.39 & $5.3-6.6$ & 0.82 \\
4. Familial & 288 & 11 & 4.17 & 0.58 & $3.5-5.5$ & 0.74 \\
5. Humble & 290 & 10 & 4.97 & 0.70 & $3.8-6.1$ & 0.72 \\
6. Faithful & 288 & 8 & 5.69 & 0.57 & $4.7-6.3$ & 0.83 \\
7. Receptive & 288 & 10 & 5.71 & 0.76 & $4.5-6.6$ & 0.73 \\
\hline
\end{tabular}

(C) International Association for Applied Psychology, 2001. 
as shown in our data and as discussed and predicted by the above mentioned authors, then relating leadership effectiveness to planning and to the concern for future makes more sense. The fourth factor, familial, refers to an attribute emphasising one's willingness to sacrifice personal gains for the sake of family interests, being involved and enjoying home and family life, and being devoted to home and family and so on. According to a number of historians and biographers (e.g. Forbis, 1980; Hillman, 1990; Adams, 1972), family has had a major impact on the historical development of Iranian culture. Family has been the cornerstone of Iranian social structure and order. In order to preserve the basic building block of society, tradition has required that "the family be led by an all powerful leader commanding unquestioning obedience from every member of the kinship group. In effect, [this] ... creates in a miniature the Iranian hierarchical structure of ruler and subject" (Mackey, 1996, p. 95). This particular feature of the Iranian culture helps explain other aspects of the leadership and its interaction with cultural values. For example, the role of the senior male in ruling the family, the role of women members of the family and the cultural value of gender egalitarianism, the value placed on the system of patriarchy and the resultant role of the leader in this context. All of these help develop a fairly complex picture of interrelationships among leadership preferences and the cultural values and assumptions embedded in two and a half millennia of history.

The fifth factor, which we called humble, refers to the attribute of attaching low estimation to one's importance, using subtle ways of communicating this to others, presenting oneself in a humble and modest way, and being hard working, caring, and down-to-earth. The sixth factor was termed faithful. This factor referred to the leadership attribute of believing in religion, acting according to the standards of religious doctrine and morals, being earnestly religious, foregoing self-interest and making personal sacrifices, and following established procedures. Both of these latter leadership factors refer to a particular set of attributes that are related to culturally specific leadership behaviors in Iran. The connection between leadership and religion has always existed in Iranian culture. From the ancient Zoroastrian times to the Islamic era, the concepts of leadership and charisma in Iran have been connected to the possession of either a sign bestowed on the leader by the Zoroastrian's force of good and Sire of Truth, Ahura Mazda, or a deep belief in religion (Shia Islam) and support from the Shia Moslem religious communities (Forbis, 1980; Mackey, 1996). The final leadership factor was receptive. This referred to the leader being: anticipatory, benevolent, clear, administratively skilled, conscious of status and class in social setting, and amicable.

The first two factors (i.e. supportive and dictatorial factors) were further analyzed, as they include larger number of items. The second-order factor analyses of these two initial factors are shown in Tables 4 and 5. As shown

(C) International Association for Applied Psychology, 2001. 
TABLE 4

Summary of Factor Analysis for "Supportive" Leadership Items

Examples of Items Factor 1 Factor 2 Factor 3 Factor 4 Factor 5 Factor 6 Factor 7

Examples of Items $\quad$ Factor 1 Factor 2 Factor 3 Factor 4 Factor 5 Factor 6 Factor 7 Dynamic Considerate Fair Positive Collaborative Tactful Modest

\begin{tabular}{|c|c|c|c|c|c|c|c|}
\hline 1. Robust & 0.687 & & & & & & \\
\hline 2. Daring & 0.644 & & & & & & \\
\hline 3. Dynamic & 0.627 & & & & & & \\
\hline 4. Encouraging & 0.564 & & & & & & \\
\hline $\begin{array}{l}\text { 5. Improvement- } \\
\text { oriented }\end{array}$ & 0.561 & & & & & & \\
\hline 6. Socially sensitive & & 0.734 & & & & & \\
\hline $\begin{array}{l}\text { 7. Socially } \\
\text { supportive }\end{array}$ & & 0.690 & & & & & \\
\hline 8. Understanding & & 0.623 & & & & & \\
\hline 9. Considerate & & 0.538 & & & & & \\
\hline 10. Normative & & 0.516 & & & & & \\
\hline 11. Fraternal & & & 0.660 & & & & \\
\hline 12. Just & & & 0.622 & & & & \\
\hline 13. Honest & & & 0.571 & & & & \\
\hline 14. Kind & & & 0.546 & & & & \\
\hline 15. Compassionate & & & 0.538 & & & & \\
\hline 16. Positive & & & & 0.720 & & & \\
\hline 17. Peace-maker & & & & 0.703 & & & \\
\hline 18. Prepared & & & & 0.607 & & & \\
\hline $\begin{array}{l}\text { 19. Performance- } \\
\text { oriented }\end{array}$ & & & & 0.546 & & & \\
\hline 20. Inspirational & & & & 0.539 & & & \\
\hline 21. Calm & & & & & 0.695 & & \\
\hline 22. Mediator & & & & & 0.615 & & \\
\hline 23. Collaborative & & & & & 0.595 & & \\
\hline 24. Cooperative & & & & & 0.533 & & \\
\hline 25. Consultative & & & & & 0.486 & & \\
\hline 26. Graceful & & & & & & 0.711 & \\
\hline 27. Group-oriented & & & & & & 0.564 & \\
\hline 28. Status-conscious & & & & & & 0.416 & \\
\hline 29. Diplomatic & & & & & & 0.406 & \\
\hline 30. Non-excessive & & & & & & & 0.648 \\
\hline 31. Non-excitable & & & & & & & 0.584 \\
\hline 32. Modest & & & & & & & 0.415 \\
\hline No. of Items & 9 & 8 & 8 & 6 & 5 & 4 & 3 \\
\hline Eigenvalue & 16.45 & 1.96 & 1.83 & 1.53 & 1.38 & 1.32 & 1.23 \\
\hline $\begin{array}{l}\% \text { of variance } \\
\text { explained }\end{array}$ & 35.76 & 40.01 & 44.00 & 47.32 & 50.31 & 53.18 & 55.85 \\
\hline
\end{tabular}

(C) International Association for Applied Psychology, 2001. 
in Tables 4 and 5, these yielded a number of unique factors that represented dimensions of leadership from the perspective of the Iranian managers studied. Table 4 shows the results of a varimax-rotated factors analysis for the supportive leadership scale. It produced seven factors accounting for over 56 per cent of variance. These were: dynamic, considerate, fair, positive, collaborative, tactful, and modest. These factors in many ways portray attributes of a caring, credible, socially capable, modest, humble, collaborative, and dynamic leader that Iranian culture has supported over the centuries (Mackay, 1996).

TABLE 5

Summary of Factor Analysis for "Dictatorial" Leadership Items

\begin{tabular}{|c|c|c|c|c|c|}
\hline Examples of Items & $\begin{array}{l}\text { Factor } 1 \\
\text { Deceitful }\end{array}$ & $\begin{array}{c}\text { Factor } 2 \\
\text { Self-Important }\end{array}$ & $\begin{array}{c}\text { Factor } 3 \\
\text { Individualistic }\end{array}$ & $\begin{array}{l}\text { Factor } 4 \\
\text { Vindictive }\end{array}$ & $\begin{array}{r}\text { Factor } 5 \\
\text { Willful }\end{array}$ \\
\hline 1. Hostile & 0.752 & & & & \\
\hline 2. Dishonest & 0.724 & & & & \\
\hline 3. Cunning & 0.660 & & & & \\
\hline 4. Distant & 0.640 & & & & \\
\hline 5. Provocateur & 0.610 & & & & \\
\hline 6. Directive & & 0.653 & & & \\
\hline 7. Demanding & & 0.643 & & & \\
\hline 8. Egocentric & & 0.603 & & & \\
\hline 9. Egotistical & & 0.599 & & & \\
\hline 10. Domineering & & 0.591 & & & \\
\hline $\begin{array}{l}\text { 11. Individually- } \\
\text { oriented }\end{array}$ & & & 0.753 & & \\
\hline $\begin{array}{l}\text { 12. Individually } \\
\text { competitive }\end{array}$ & & & 0.679 & & \\
\hline 13. Aloof & & & 0.560 & & \\
\hline 14. Non-delegator & & & 0.543 & & \\
\hline 15. Asocial & & & 0.492 & & \\
\hline 16. Unchanging & & & & 0.745 & \\
\hline 17. Tyrannical & & & & 0.604 & \\
\hline 18. Vindictive & & & & 0.547 & \\
\hline 19. Secretive & & & & 0.488 & \\
\hline 20. Skeptical & & & & 0.451 & \\
\hline 21. Unique & & & & & 0.671 \\
\hline 22. Strong-minded & & & & & 0.663 \\
\hline 23. Willful & & & & & 0.626 \\
\hline 24. Communicative & & & & & 0.523 \\
\hline No. of Items & 9 & 7 & 8 & 6 & 5 \\
\hline Eigenvalue & 12.26 & 2.24 & 1.76 & 1.63 & 1.48 \\
\hline $\begin{array}{l}\% \text { of variance } \\
\text { explained }\end{array}$ & 32.26 & 38.16 & 42.79 & 47.07 & 50.96 \\
\hline
\end{tabular}

(C) International Association for Applied Psychology, 2001. 
Table 5 shows the same procedure for the dictatorial factor. The analysis shows five factors accounting for about 50 per cent of the variance. The second-order factors were: deceitful, self-important, individualistic, vindictive, and willful. Most of these attributes bear resemblance to Zoroastrian's force of destruction, the spirit of darkness, and the Destroyer-Ahriman (Irving, 1979, p. 19; Dhalla, 1922, p. 33). The deceitful, vindictive, and self-oriented leader is the one most closely associated with Ahriman and will need to be redeemed. Under the Zoroastrian guides, men and women's primary role in society is as redeemers and perfecters of a flawed world - a world in which the fate of an individual or a leader "... depends on how well he or she acts in the cosmic balance between the powers of light and powers of darkness" (Mackey, 1996, p. 16). Due to the considerable influence of Zoroastrianism on Iran's subsequent move to Islam, and thus the creation of Shia Islam, many of the same beliefs were carried forward and have become deeply rooted in the cultural fabric of Iranians and the way they think about effective leadership.

\section{CONCLUDING COMMENTS}

This study has embarked on empirically examining the culture and leadership in Iran. To our knowledge, there is no other published work that has addressed the same issues. The conceptual and methodological aspects of the study have been guided by the GLOBE project (House et al., 1999; see also Hartog et al., 1999). The data were collected from 300 middle level managers from over 60 organisations in three industries (telecommunications, food processing, and banking). The primary purpose of this paper was to examine the etic and emic aspect of leadership in Iran and to develop a profile of effective leadership for Iran. The paper also reported and elaborated on the dimensions of Iran's culture using GLOBE categories.

In terms of the leadership, the results showed seven scales: supportive, dictatorial, planner, familial, humble, faithful, and receptive. The first two factors were similar to the "etic" charismatic and narcissistic dimensions of leadership found in other GLOBE studies (e.g. Den Hartog et al., 1999; Ashkanasy et al., 2000). When these two factors were further analyzed, a number of second-order factors were generated that require further analysis. The remaining five leadership factors from the main factor analysis are regarded as "emic" aspects of leadership. Attributes such as familial, humble, and faithful have more of a historical root and can be linked to the role of family and religion in the long history of the country. The others, planner and receptive, we argued, may be more readily related to more recent social changes that Iranian society has been going through since the revolution in 1979 (e.g. Wright, 1992, 2000).

(C) International Association for Applied Psychology, 2001. 
When we examined the societal culture using the nine GLOBE dimensions, Iran appeared to have the lowest score on assertiveness among all the 61 countries, and had relatively lower scores on uncertainty avoidance, societal collectivism, future orientation, and gender egalitarianism. On the other hand, Iran had the third highest score on in-group collectivism, and had relatively high scores on performance orientation, power distance, and humane orientation. In terms of the desires to change the culture, the data showed that Iranians are most interested in reducing the power distance and increasing the future orientation aspects of the societal culture.

Further analysis will shed more light on the complex interconnectedness of the effective attributes of a leader and the culture of Iran. However, this paper has demonstrated a number of unique and interesting aspects of leadership. The results need to be understood within the modern day context of Iran as well as the historical-cultural background of this country. According to the historians, Iranians have always lived within overlapping orbits of powerful authority figures. For centuries, Iranian culture has had a deep-rooted authoritarian tradition (Mackey, 1996; Hillman, 1990). In addition, the notion of leadership has historically been very closely associated with this tradition. "In the Iranian concept of leadership, a leader possesses charisma because he [she] is endowed with supernatural powers, or at least exceptional qualities, that set him [her] apart from ordinary humans.... [The leader] commands a special grace, and otherworldly quality that engenders trust, commitment, and an irresistible desire to follow. The reality that charismatic figures bearing a new dynasty often appeared during pivotal points of history to sustain the Iranian nation reinforced the concept of the hero king. Thus monarchy becomes a function of personality where authority flowed to the charismatic leader rather than being imposed by the institution of the throne. Furthermore, this ideal and expectation of charismatic leadership constitutes one of Iranian culture's defining characteristics" (Mackey, 1996, p. 96).

Given this background, we maintain that the study has demonstrated leadership attributes and factors that would not have appeared as an outcome of our study had it not been for (i) the unique aspects of the Iranian culture (the emic aspects of leadership), and (ii) the generalisablitiy of some attributes of leadership that could be regarded as culture free (the etic aspect of leadership). Nevertheless, the cultural dimensions and the leadership attributes that emerged from this study point to the juxtaposing of Iranian culture between two complex but interlocking traditions. One has its roots in ancient Persia, the other in Islam. Iran since the seventh century has survived these balancing forces with its Persian and Islamic faces sometimes relaxed in harmony but as often creased with tension (Mackey, 1996; Wright, 2000). These initial findings of our work are a small step toward exploring such deep cultural tensions and traditions.

(C) International Association for Applied Psychology, 2001. 


\section{REFERENCES}

Adams, C.J. (Ed.) (1972). Iranian civilization and culture: Essays in honor of the 2500 anniversary of the founding of the Persian empire. Montreal: McGill University's Institute of Islamic Studies.

Adler, N.J., Doktor, R., \& Redding, S.G. (1986). From the Atlantic to the Pacific century: Cross-cultural management reviewed. 1986 Yearly Review of the Journal of Management, 12(2), 295-318.

Ashkanasy, N., Kennedy, J., \& Trevor-Roberts, E. (2000). The GLOBE Project: Australian and New Zealand leadership compared. Paper presented at XXVII International Congress of Psychology, Stockholm, Sweden, July.

Bass, B.M. (1985). Leadership and performance beyond expectations. New York: The Free Press.

Bass, B.M. (1997). Does the transactional-transformational leadership paradigm transcend organizational and national boundaries? American Psychologist, February, 130-139.

Bennis, W.G., \& Nanus, G. (1985). Leaders. New York: Harper \& Row.

Britannica book of the year (1999). London: Encyclopedia Britannica.

Burns, J.M. (1978). Leadership. New York: Harper and Row.

Child, J.D., \& Tayeb, M. (1983). Theoretical perspectives in cross-national research. International Studies of Management and Organisation, Winter, 32-70.

Conger, J.A. (1989). The charismatic leader: Behind the mystique of exceptional leadership. San Francisco: Jossey-Bass.

Conger J., \& Kanungo, R.A. (1987). Toward a behavioural theory of charismatic leadership of organizational settings. Academy of Management Review, 12(4), 637-643.

Dastmalchian, A., \& Javidan, M. (1998). High-commitment leadership: A study of Iranian executives. Journal of Comparative International Management, 1(1), $23-37$.

Dastmalchian, A., \& Javidan, M. (2000). GLOBE findings: Culture and leadership in Iran. Paper presented at XXVII International Congress of Psychology, Stockholm, Sweden, July.

Den Hartog, N.D., House, R.J., Hanges, P.J., Ruiz-Quintanilla, S.A., \& Dorfman, P.W. (1999). Cultural specific and cross culturally generalizable implicit leadership theories: Are attributes of charismatic/transformational leadership universally endorsed? Leadership Quarterly, 10(2), 219-256.

Den Hartog, N.D., Dorfman, P.W., Hanges, P.J., House, R.J., Other GLOBE Members, and Ruiz-Quintanilla, S.A. (2000). Leadership across cultures: Are attributes of charismatic/transformational leadership universally endorsed? Paper presented at XXVII International Congress of Psychology, Stockholm, Sweden, July.

Dhalla, M.N. (1922). Zoroastrian civilization: From the earlier times to the downfall of the last Zoroastrian Empire 651 AD. New York: Oxford University Press.

The Economist (1996). The man in the Baghdad cafe. 9 November, 23-26.

Erez, M., \& Earley, C. (1993). Culture, self-identity and work. New York: Oxford University Press.

(C) International Association for Applied Psychology, 2001. 
Europa world year book (1997). Vol. 1, Part 1: International organizations. Brussels: Europa Publications.

Fairbanks, S.C. (1997). A new era for Iran. Middle East Policy, 5(3), 48-59.

Forbis, W.H. (1980). The fall of the peacock throne: The story of Iran. New York: Harper and Row.

Goreishi, A., \& Zahedi, D. (1997). Prospects for change in Iran. Middle East Policy, 5(1), 90-99.

Halpin, A.W., \& Winer, B.J. (1957). A factorial study of the leader behavior descriptions. In R.M. Stogdill \& A.E. Coones (Eds.), Leader behavior: Its description and measurement. Columbus: Ohio State University.

Hillman, M. (1990). Iranian culture: A Persian view. New York: University Press of America.

Hofstede, G. (1980). Culture's consequences. International differences in work-related values. Beverly Hills: Sage.

Hofstede, G., \& Bond, M.H. (1988). The Confucius connection: From cultural roots to economic growth. Organizational Dynamics, 16, 4-21.

House, R.J. (1977). A 1976 theory of charismatic leadership. In J.G. Hunt \& L.L. Lawson (Eds.), Leadership: The cutting edge (pp. 189-207). Carbondale: Southern Illinois University Press.

House, R.J., Hanges, P.J., Ruiz-Quintanilla, S.A., Dorfman, P.W., Javidan, M., Dickson, M., Gupta, V., et al (1999). Cultural influences on leadership and organisations: Project GLOBE. In W.H. Mobley (Ed.), Advances in global leadership, Vol. 1, pp. 171-233. Stanford, CN: JAI Press.

Irving, C. (1979). Crossroads of civilization: 3000 years of Persian history. New York: Barnes and Noble Books.

Javidan, M. (1994). Vision and inspiration. Proceedings of the Third Annual World Business Congress, Penang, Malaysia.

Javidan, M. (1996). Vision and inspiration: A study of Iranian executives. Journal of Transnational Management Development, 2(2), 69-85.

Javidan, M., \& Dastmalchian, A. (1993). The determinants of effective senior management performance: A cross-cultural study. Best Paper Proceedings of the Academy of Management Meeting, Atlanta, Georgia, p. 475.

Javidan, M., \& Dastmalchian, A. (1995). Visionary management: A comparison of Taiwanese and Iranian executives. Proceedings of 1st Asian Academy of Management, Penang, USM, Malaysia, pp. 365-379.

Katz, D., \& Kahn, R.L. (1952). Some recent findings in human relations research. In E. Swanson, T. Newcomb, \& E. Hartley (Eds.), Readings in social psychology. New York: Holt, Reinhart, and Winston.

Kotter, J. (1988). The leadership factor. New York: Free Press.

Lammers, C.J., \& Hickson, D.J. (Eds.) (1979). Organizations alike and unlike: International and inter-institutional studies in the sociology of organizations. London: Routledge \& Kegan Paul.

Levitt, T. (1983). The globalization of markets. Harvard Business Review, 83(3), 92-102.

Lewis, B. (1995). The Middle East. London: Weidenfeld and Nicolson.

Mackey, S. (1996). The Iranians: Persia, Islam and the soul of a nation. New York: Plume Books.

(C) International Association for Applied Psychology, 2001. 
Rouleau, E. (1995). The Islamic Republic of Iran: Paradoxes and contradictions in a changing society. Middle East Insights, X, 5 (July-Aug.), 54-58.

Sashkin, M. (1988). The visionary leader. In J.A. Conger, R.N. Kanungo, \& Associates (Eds.), Charismatic leadership (pp. 122-160). San Francisco: JosseyBass.

Stogdill, R.M. (1948). Personal factors associated with leadership: A survey of the literature. Journal of Psychology, 25, 35-71.

Stogdill, R.M. (1974). Handbook of leadership: A survey of theory and research. New York: Free Press.

Tichy, J.P., \& Devanna, M.A. (1986). The transformational leader. New York: John Wiley.

United Nations (1997). Statistical yearbook for Asia and the Pacific. New York: United Nations.

Woodward, J. (1958). Management and technology. London: HMSO.

Wright, R. (1992). Islam, democracy, and the West. Foreign Affairs, 71(3), 131-145.

Wright, R. (2000). Iran's new revolution. Foreign Affairs, 79(1), 133-145.

Yavas, B.F. (1995). Quality management practices worldwide: Convergence or divergence? Quality Progress, 28(10), 57-61.

Yukl, G.A. (1981). Leadership in organizations. Englewood Cliffs, NJ: Prentice-Hall.

Yukl, G.A. (1989). Managerial leadership: A review of theory and research. Journal of Management, 15(2), 251-289.

(C) International Association for Applied Psychology, 2001. 
Appendix

Complete Factor Analysis for Iranian Leadership Scales

\begin{tabular}{|c|c|c|c|c|c|c|c|}
\hline $\begin{array}{l}\text { Current } \\
\text { Item }\end{array}$ & Characteristic or Behavior and Definition & $\begin{array}{l}\text { Factor } 1 \\
\text { Supportive }\end{array}$ & $\begin{array}{c}\text { Factor } 2 \\
\text { Dictatorial }\end{array}$ & $\begin{array}{l}\text { Factor } 3 \\
\text { Visionary }\end{array}$ & $\begin{array}{lr}\text { Factor } 4 & \text { Factor } 5 \\
\text { Familial } & \text { Humble }\end{array}$ & $\begin{array}{l}\text { Factor } 6 \\
\text { Faithful }\end{array}$ & $\begin{array}{l}\text { Factor } 7 \\
\text { Receptive }\end{array}$ \\
\hline E55 & $\begin{array}{l}\text { Encouraging: Gives courage, confidence or hope through } \\
\text { urging and advice }\end{array}$ & 0.733 & & & & & \\
\hline E135 & Robust: Not fragile, strong, healthy & 0.715 & & & & & \\
\hline E146 & Sincere: Means what he/she says, earnest & 0.713 & & & & & \\
\hline E159 & Understanding: Understands others and shares feelings & 0.704 & & & & & \\
\hline E149 & Socially Supportive: Shows concern for the feelings of others & 0.695 & & & & & \\
\hline E148 & Socially Sensitive: Aware of the feelings of others & 0.673 & & & & & \\
\hline E66 & Fraternal: Tends to be a good friend of subordinates & 0.657 & & & & & \\
\hline E96 & Kind: Friendly and understanding & 0.655 & & & & & \\
\hline E115 & Nurturing: Behaves in a caring way & 0.639 & & & & & \\
\hline E77 & Humane: Compassionate, concerned with welfare of others & 0.639 & & & & & \\
\hline E28 & Considerate: Respects others' needs and feelings & 0.637 & & & & & \\
\hline E93 & Intuitive: Has extra insight & 0.612 & & & & & \\
\hline E110 & $\begin{array}{l}\text { Non-excitable: Not easily psychologically aroused, excited or } \\
\text { upset }\end{array}$ & 0.612 & & & & & \\
\hline E86 & Industrious: A hard worker & 0.606 & & & & & \\
\hline E80 & $\begin{array}{l}\text { Improvement-oriented: Seeks continuous performance } \\
\text { improvement }\end{array}$ & 0.600 & & & & & \\
\hline E26 & $\begin{array}{l}\text { Compassionate: Has empathy for others, inclined to be } \\
\text { helpful or show mercy }\end{array}$ & 0.589 & & & & & \\
\hline E68 & $\begin{array}{l}\text { Generous: Willing to give time, money, resources and help to } \\
\text { others }\end{array}$ & 0.585 & & & & & \\
\hline E71 & Group-oriented: Concerned with the welfare of the group & 0.580 & & & & & \\
\hline E29 & $\begin{array}{l}\text { Consultative: Consults with others before making plans or } \\
\text { taking action }\end{array}$ & 0.566 & & & & & \\
\hline E36 & Daring: Shows courage & 0.555 & & & & & \\
\hline
\end{tabular}


E109 Non-excessive: Does not go to extremes, moderate 0.546

E128 Prepared: Is ready for future events

E41 Diplomatic: Communicative acumen, skilled at interpersonal 0.537

relations, tactful

E48 Dynamic: Highly involved, energetic, enthused, motivated 0.526

Just: Acts according to what is right or fair

E104 Modest: Does not boast, presents self in a humble manner 0.519

E70 Graceful: Having or showing grace, elegance 0.517

E31 Cooperative: Willing to work in a collaborative way with 0.515 others

E152 Status-conscious: Aware of others' socially acceptable status 0.502

Patient: Has and shows patience 0.499

Performance-oriented: Sets high standards of performance $\quad 0.496$

Collaborative: Works jointly with others 0.491

Sports-oriented: Interested in sports $\quad 0.485$

Coordinator: Integrates work of subordinates by codirection 0.484

and communication

Intragroup Face-saver: Ensures that other group members are

0.478 not embarrassed or shamed

Spiritual: Places emphasis on spiritual, not material matter

E112 Non-manipulative: Does not use deceit or trickery to gain

0.463

personal advantage

E88 Inspirational: Inspires emotions, beliefs, values, and behaviors

0.462 of others; inspires others to work hard

E114 Normative: Behaves according to the norms of his or her

group

E155 Sympathetic: Has sympathy for others

E127 Positive: Generally optimistic and confident 0.424

$\begin{array}{ll}\text { E102 Mediator: Intervenes to solve conflicts between individuals } & 0.400\end{array}$

E123 Peace-Maker: Adept in resolving social disputes among 0.399

$\begin{array}{lll}\text { E19 Calm: Not easily distressed } & 0.399\end{array}$ 
Facto

Factor 4 Factor 5 Factor 6 Factor 7 Supportive Dictatorial Visionary Familial Humble Faithful Receptive

E75 Honest: Speaks truthfully 0.388

E165 Win/Win Problem Solver: Able to identify solutions which

0.388

satisfy individuals with diverse and conflicting interests

E51 Egotistical: Conceited, convinced of own abilities

0.377

E107 Non-cooperative: Unwilling to work jointly with others

Non-delegator: Unwilling or unable to relinquish control of

0.682

projects or tasks

E14 Autocratic: Makes decisions in dictatorial way

0.675

Tyrannical: Acts like a tyrant or despot; imperious

0.644

0.644

Ruthless: Punitive; having no pity or compassion

0.638

E138

Ruler: Is in charge and does not tolerate disagreement or

0.632

questioning, gives orders

E162 Vindictive: Vengeful; seeks revenge when wronged

0.628

Egocentric: Self-absorbed, thoughts focus mostly on one's self $\quad 0.620$

E164 Willful: Strong-willed, determined, resolute, persistent 0.610

E40 Dictatorial: Forces her/his values and opinions on others

E9 Asocial: Avoids people or groups, prefers own company

0.583

0.582

Provocateur: Stimulates unrest

E35 Cynical: Tends to believe the worst about people and events

0.580

0.566

Cunning: Sly, deceitful, full of guile

0.559

0.557

0.553

0.548

Directive: Tends to give orders, commands, and directions

0.547

Irritable: Moody; easily agitated

0.547

opinions of others

E47

Domineering: Inclined to dominate others 
E139 Secretive: Tends to conceal information from others

Hostile: Actively unfriendly, acts negatively toward others

Individually Competitive: Prefers to compete as an individual

rather than as a member of a team

E113 Non-participative: Does not participate with others 0.528

E8 Arrogant: Presumptuous or overbearing

Dishonest: Fraudulent, insincere

Individually-oriented: Concerned with and places high values

on preserving individual rather than group needs

E12 Authoritarian: Gives orders and does not accept any

questions or discussion about them

E98 Loner: Works and acts separately from others

Strong-minded: Strong convictions, willful

Excellence-oriented: Strives for excellence in performance of

E45 Distant: Aloof, stands off from others, difficult to become

friends with

Unique: An unusual person, has characteristics or behaviors

Communicative: Communicates with others frequently

0.366

E158 Unchanging: Steady, consistent, behaves the same way over

0.364

E126 Plans ahead: Anticipates and prepares in advance

Foresight: Anticipates possible future events

Informed: Knowledgeable; aware of information

0.603

E163 Visionary: Has a vision and imagination of the future

0.603

Future-oriented: Makes plans and takes actions based on

0.601

0.582 future goals

E119 Organised: Well organised, methodical, orderly 
Current

Item

E166

E166

E53

Worldly: Interested in temporal events, has a world outlook

Factor 1

Supportive

Characteristic or Behavior and Definition

Elitist: Believes that a small number of people with similar
Factor 2 Factor 3 Factor 4 Factor 5 Factor 6 Factor 7

backgrounds are superior and should enjoy privileges

E52 Elegant: Graceful, precise in movement and appearance

E117 Obsessive: Extremely preoccupied with almost all work tasks

E60 Extremely Confident: Thinks of one's own ability as

exceptionally high in almost all matters

E74 Home-oriented: Likes to be at home, enjoys home life

E99 Loyal 1: Stays with and supports friends even when they have substantial problems or difficulties

E62 Familial: Willing to sacrifice personal gain for the sake of his her family's interests and welfare

E72 Habitual: Given to a constant, regular routine

E27 Compromiser: Willing to yield own demands to meet preferences or requirements of others

E46 Domestic: Devoted to home and family

E65 Formal: Acts in accordance with rules, conventions and ceremonies

E103 Micro-manager: An extremely close supervisor, one who insists on making all decisions

E54 Emotional: Expresses emotions frequently and openly

E82 Indirect: Does not go straight to the point, uses metaphors and allegories to communicate

E134 Ritualistic: Uses a prescribed order to carry out procedures

E78 Humble: Holds and shows low estimation of his/her own importance
0.525

0.440

0.436

0.394

0.366

0.629

0.504

0.489

0.472

0.438

0.434

0.429

0.407

0.396

0.374

0.373 
Current Characteristic or Behavior and Definition $\quad$ Factor $1 \quad$ Factor 2 Factor 3 Factor 4 Factor 5 Factor $6 \quad$ Factor 7

Item Supportive Dictatorial Visionary Familial Humble Faithful Receptive

E24 Collectively-oriented: Sacrifices self-interest to the interests

0.387

of the group to which he/she belongs

E6 Amicable: Has a friendly attitude

E11 Athletic: Good at sports

E10 Assertive: Tends to declare her/his rights, preferences, or opinions firmly

$\%$ Variance (cumulative)

\begin{tabular}{|c|c|c|c|c|c|c|}
\hline & & & & & & $\begin{array}{l}0.385 \\
0.370 \\
0.363\end{array}$ \\
\hline 46 & 38 & 12 & 11 & 10 & 8 & 10 \\
\hline 26.30 & 12.96 & 6.31 & 5.79 & 5.04 & 3.60 & 3.52 \\
\hline 16.65 & 24.85 & 28.84 & 32.51 & 35.69 & 37.97 & 40.20 \\
\hline
\end{tabular}


Copyright of Applied Psychology: An International Review is the property of Blackwell Publishing Limited and its content may not be copied or emailed to multiple sites or posted to a listserv without the copyright holder's express written permission. However, users may print, download, or email articles for individual use. 